\title{
THE INCREASING THE DURATION OF FUNCTIONAL BEVERAGES METHODS
}

\author{
Marina V. Gernet ${ }^{1,2}$, Irina N. Gribkova ${ }^{1 *}$, Olga A. Borisenko ${ }^{1}$ \\ ${ }^{1}$ All-Russian Scientific Research Institute of the Brewing, Non-Alcoholic and Wine Industry - \\ Branch of the V.M. Gorbatov Federal Research Center for Food Systems of RAS, Moscow, Russia \\ ${ }^{2}$ Moscow State University of Food Production, Moscow, Russia
}

\section{KEY WORDS:}

functional drinks, shelf life, a group of functional compounds, processing method, flavanoids

\begin{abstract}
In the Russia beverage market, functional beverages are increasingly popular with the population due to their intensive lifestyle and worsening environmental situation. Of great importance is the shelf life of drinks, since they determine the presence in the composition of useful nutrients that affect the various systems of functioning of the human body. The main groups of functional compounds are given. Ways to increase the shelf life of beverages, all aspects and their impact on the safety of the functional components of beverages are considered. The role of flavonoids as one of the groups of functional compounds has been evaluated. Recent studies on the effect of certain functional compounds on each other are given.
\end{abstract}

\section{Introduction}

Drinks are the most accessible food form relative to nutrients entering the human body, providing the body's needs for various compounds. This is explained by the possibility of having nutrients in a dissolved state for their better absorption.

There are many types of beverages and this is related to the production technology (carbonated / non-carbonated, fermented beverages / non-alcoholic beverages obtained by blending ingredients, etc.), raw materials (vegetable / animal origin), functional orientation (content in its composition ingredients responsible for the biological value of the product), etc.

Recently, in connection with the deteriorating environment it has become more significant to lead a healthy lifestyle. This is due, inter alia, to the consumption of beverages enriched with compounds, which allow maintaining body functions and leveling the negative effect of negative environmental factors on the whole on health.

An important issue regarding the quality of such beverages is the shelf life. The trading network is more willing to work with manufacturers who guarantee sufficiently long storage periods for their products. Therefore, there is a reasonable problem of preserving functional compounds quantity and quality in beverages during long periods of beverages storage.

The purpose of the work is to analyze the market of beverages, including functional ones, with regard to ways to increase shelf life without affecting the quantitative and qualitative composition of functional compounds.

\section{Main part}

It is known that functional drinks are enriched with useful nutrients groups of general or directed action product for various groups of the population, which make it possible to improve the human body immunoresistance to diseases arising from either unfavorable ecological conditions or related to the failure of physiological processes [1].

This group of drinks owes to vitamins, microelements, dietary fibers, probiotics, amino acids, volatile compounds, organic acids, antioxidants, etc. presence in its composition for functional properties [2].

The beer and soft drinks industry regulatory documents spell out clear requirements as to whether a drink can be attributed to a functional group: this is possible if one or more functional components are present in an amount from 10 to $50 \%$ of the daily intake [3].
There are various functional beverage divisions $[4,5]$. This is due to the direction of particular product useful nutrients action for different groups of the population.

However, in our opinion, the functional drinks division can be supplemented with fermentation and blending beverages produced by mixing the ingredients in the prescribed manner.

Plant material is a rich source of useful nutrients, it is enriched with such biologically active substances as anthocyanins, polyphenols, carotenoids, vitamins, oligosaccharides, amino acids [6]

The presence of the fermentation as technological stage makes it possible to enrich the drink with the vital activity products of microorganisms that are also related to functional compounds these are alcohols, ethers, carbonyl compounds, organic acids, vitamins, amino acids, etc., which can also enhance the beneficial effect of each other.

Table 1 presents functional food compounds main categories, obtained either directly from vegetable raw materials, or during fermentation [7].

Table 1

\begin{tabular}{ll}
\hline Dietary Fiber & Vitamins \\
\hline Oligosaccharides & Choline \\
\hline Sugar alcohols & Bifidobacterium \\
\hline Amino acids, peptides, proteids & Mineral components \\
\hline Glycosides & $\begin{array}{l}\text { Polyunsaturated Fatty Acids, } \\
\text { Antioxidants }\end{array}$ \\
\hline Alcohols & Cytamines \\
\hline Organic Acids & Vegetable Enzymes
\end{tabular}

Among listed above functional nutrients, almost all are thermally unstable and undergo chemical changes associated with oxidation under the influence of various factors (elevated temperature, changes in the acidity of the environment, the presence of oxygen, ultraviolet, etc.) $[8,9,10,11,12,13,14]$.

Therefore, it is very important, especially in the case of enriched with useful nutrients beverages production, to apply technological methods that allow to keep functional compounds in an active form for the longest possible time.

There are several ways that solved the biological stability problem of the beverage composition in the classical technology of beverages production, including functional ones: 
$\square$ pasteurization (processing temperature not higher than $\left.70{ }^{\circ} \mathrm{C}\right)$

$\square$ hot bottling;

$\square$ the safety compounds use (benzoic, sorbic acids and their salts - sodium benzoate and potassium sorbate, as well as hydroxy derivatives 1,4 naphthoquinone - juglone and plumbagin) [15]. All of them are aimed to suppressing the extraneous microflora development, due to which stability of the physicochemical beverage composition is achieved.

In addition to the classical methods of enhancing the biological beverages stability, there are other, that including innovative methods associated with vacuum evaporation, the use of pulsation, ultrafiltration, cryopreservation, etc. $[16,17,18,19]$.

The concentration method is acceptable because it comfortable to beverage producers under conditions of mini-production, when large production areas are not required. However, from the point of view of biological stability, this technique is very doubtful, because it connected with impact on useful nutrients, leading to their inactivation or loss of functional properties [10].

Another way to increase beverages shelf life is cold filtration [20], ultrafiltration [21], the ultrasound use with the anthocyanogen raw material confirmed preservation [22], the radiation technology use [23,24].

However, these methods, as already mentioned, will lead to additional costs for the manufacturer in terms of energy consumption, specialized personnel for equipment maintenance, as well as will take away some of the production space.

Increasing shelf life research is also aimed at the use of nanostructured particles based preservatives new types. Preservatives, as is well known, suppress the development of extraneous microflora in food products, in particular beverages. Thus, there are studies on the use of lactic acid associates with silver nanoparticles [25], as well as with lichen nanoparticles [26].

However, there is evidence of the microflora development suppression by nanochayats duration, in particular silver, only for 8 months in the literature [27]. The researchers also noted that it is important to take into account the dispersion medium (beverage) nature and the nanoparticle suspensions storage time in order to effectively use them as preservatives [28].

Researchers are trying to apply raw materials new types for the functional compounds enrichment of products and the extension shelf life periods [29,30,31]. There is a technique when high content of antioxidants plant materials are used as raw materials in technology [2,32,33,39].

Among the plant antioxidants, phenolic compounds, in particular flavonoids, are widely represented. These compounds, in addition to direct antiradical action, bind metals with a transition valence, due to which inhibition of free radical processes in cells occurs [40].

It was also found that flavonoids also affect signaling processes in living systems, due to specific interaction with proteins that perform regulatory functions [41]. By binding to protein and nonprotein structures, flavonoids change the functional state of the cell and the whole organism.

The mechanism of flavonoids and ascorbic acid interaction has been discovered, which allows maintaining the flavonoid in a reduced state, associated with a reciprocal reaction, and direction of which reaction depends entirely on the ORP of the flavonoid interacting with the ascorbate radical [42].

There is evidence that flavonoids are capable to oxidation in the literature, that is, the manifestation of prooxidant properties $[43,44,45,46,47]$. The intermediate products of the flavonoid oxidation, which are formed during such reactions, appear practically in all oxidative processes with their participation. That is, flavonoids are capable of acting both antioxidants and prooxidants, and the mechanisms of the course of these reactions have not yet been clarified.

But the flavonoid presence in the drink is not enough, since there are various factors affecting their bioavailability for the human body (ability to be absorbed by the human intestine and absorbed in the body), because fermentation drinks are characterized by a richer composition of functional compounds extracted from raw materials. Such factors include daily intake, absorption, biotransformation and excretion [48].

Scientists provide different information about the quantitative native polyphenol absorption in the intestine - from 1\% [49] to $50-70 \%[50,51]$ of the eaten polyphenols. In their opinion, it is the small intestine that serves as a place of absorption, in particular, of flavonoids. The degree of flavonoids absorption is different and depends on their form - aglycones of flavonoids and isoflavones are easily absorbed [52,53], and glycosides of flavonols, flavones and isoflavones should be pre-hydrolyzed to aglycones.

In the colon, the polyphenols are further processed by bacterial enzymes with cleavage of a heterocyclic ring containing oxygen, dehydroxylation and decarboxylation $[54,55,56]$.

It is also necessary to note the fact that the presence of concomitant other compounds in the drink can either enhance the effect of polyphenols on absorption, or suppress.

Thus, proteins reduce the polyphenol adsorption capacity, since they bind to them, and fats and alcohols intensify them [57]. Green tea catechins, grape seed oligomeric proanthocyanidins and milk thistle silibilins have been shown to be better absorbed in the form of phospholipid complexes [57]. In confirmation of the better absorbability of polyphenols against the background of the presence of alcohols, one can cite the fact that red wine polyphenols are absorbed more intensively compared to soft drinks $[58,59,60]$.

Thus, the flavonoids, as substances with anti-radical activity, are also labile and for their protection it is also necessary to choose the modes of processing products.

\section{Conclusion}

The functional drinks market is developing in terms of raw materials variety that enrich the drinks with useful nutrients; technological practices that contribute to the extension of shelf life, and related to the physico-chemical processes of processing of finished products. Accumulated and conducted scientific research aimed at clarifying the mechanisms of action and interaction of compounds responsible for the functional profile of products; on the development of technological methods that contribute to the preservation of nutritional properties of compounds during the storage period.

Thus, to solve the issue of creating a drink with the useful properties of a long shelf life, it is necessary to solve a whole range of tasks:

$\square$ pick up vegetable raw materials that are rich in beneficial compounds;

$\square$ create a technology for processing raw materials that promote the extraction of useful compounds in easily digestible bioavailable form;

$\square$ have the concept of the presence of substances that can react with antioxidants or other nutrients during the production and storage of the drink;

$\square$ to process finished products (using various methods) for the prolonged action of useful nutrients in the composition of beverages. 


\section{REFERENCES}

1. Udalova, L.P., Dogaeva, L.A., Yurikova, E.V. (2016). Innovative types of soft drinks for functional food. Advances in current natural sciences, 11, 33-37. (In Russian)

2. Baby, N.V., Solovyeva, E.N., Pomozova, V.A., Kiseleva T.F. (2013). Tonics with functional propertiest. Food Processing: Techniques and Technology, 3(30), 101-105. (In Russian)

3. GOST R52844-2007. «Alcohol-free tonic beverages. General specifications». Moscow: Standartinform. 2008. -11 p. (In Russian)

4. Dyachenko, MA, Filatov, A. Yu., Kolesnov, A. Yu., Kochetkova, A.A. (1999). Non-alcoholic beverages as the main market segment of functional products. Beer and beverages, 2, 37-40. (In Russian)

5. Schmidt, V.V. (2009). Classification of functional drinks by the method of categorization. Author's abstract of the dissertation for the scientific degree of Candidate of Technical Sciences. Kemerovo, KemTIPP. - 20 p. (In Russian)

6. Paken, P. (2010). Functional and specialty drinks. St. Petersburg: Professiya. - 496 p. ISBN 978-5-904757-08-3. (In Russian)

7. Doronin, A.F., Shenderov, B.A. (2002). Functional food. Moscow: GRANT. - 77 p. ISBN 5-94343-028-8. (In Russian)

8. Vvedenskii, A. V., Bobrinskaya, E. V., Kraschenko, T. G., Vitnova, O. A., Kuleshova, N. E. (2013). Kinetics of anodic oxidation of anions of monoand dicarboxylic aminoacids on Pt. Proceeding of Voronezh State University. Series: Chemistry. Biology. Pharmacy, 2,19-26. (In Russian)

9. Dryuk, V.G., Sklyar, S.I., Kartsev, V.G. (2018). Biological chemistry. Moscow: Yurayt. - 311 p. ISBN 978-5-534-08504-4. (In Russian)

10. Gernet, M. V., Khashukaeva, B. R., Gribkova, I. N., Kobelev, K. V., Kleimenov, M. D., Chuikina, A. M., Krechetova, A. O. (2017). The Choice of Concentrating Method in Tea-based Fermented Beverages Production. Beer and beverages, 4, 36-40. (In Russian)

11. Zhelovitskaya, A. V., Yermolaeva, E. A., Dresvyannikov, A. F. (2008). Organic compounds oxidation by a hydroxide radical generated by chemical and electrochemical methods in solutions. Bulletin of the Kazan Technological University, 6, 211-229. (In Russian)

12. Murashev, S.V. (2015). Changing the content of ascorbic acid during storage and processing. Izvestiya Saint-Petersburg state agrarian university, 41 , 64-68. (In Russian)

13. Lisitsyn, A. B., Tunieva, E. K., Gorbunova N.A. (2015). Oxidation of lipids: the mechanism, dynamics, inhibition (on materials of foreign literature). Vsyo o myase, 1, 10-15. (in Russian)

14. Baydalinova, L.S., Andronova, S.V. (2014). Polyunsaturated fatty acids of fish raw in technology of functional food. Scientific journal NRU ITMO. Series "Processes and Food Production Equipment", 3, 11-20. (In Russian)

15. Pomozova, V.A. (2006). Kvass and soft drinks production. Kemerovo, Kemerovskiy tekhnologicheskiy institut pishchevoy promyshlennosti. 148 p. ISBN 5-89289-334-0. (In Russian)

16. Evseev, N.N., Yeganyan, A.G., Zhulkov, Yu.S., Vasilenko, T.I. The method of obtaining a concentrated drink. Patent RF, no. 2215452, 2013. (In Russian)

17. 17 Shin, Z.A. The method of producing beverage concentrate. Patent RF, no. 23001784. 2016. (In Russian)

18. Makarenko, V.G. The method of obtaining a concentrated drink. Patent RF, no. 2500449. 2013. (in Russian)

19. Pogosyan, A.S. A method of concentrating drinks. Patent RF, no. 2313569. 2007. (In Russian)

20. Anon, A. (2016). Filtration reduces beverage production costs. Filtration + Separation, 53(3), 8. DOI: 10.1016/s0015-1882(16)30098-2

21. Nikitina, P.V., Novikova, L.N. The method of complex processing of unclarified and clarified concentrated Jerusalem artichoke juice. Patent RF, no. 2444915. 2012. (In Russian)

22. Salamon, B., Farkas, V., Kenesei, G., Dalmadi, I. (2017). Effect of added sugar and ascorbic acid on the anthocyanin content of high pressure processed strawberry juices during storage. Physics Journal: conference series, 950, 42-47. DOI: $10.1088 / 1742-6596 / 950 / 4 / 042005$

23. Gracheva, A. Yu., Ilyukhina, N.V., Kalinina Zh.A. (2016). Study of radiation technology influence on food products and agricultural raw materials microbiological safety. Materials of the III All-Russian Scientific and Practical Conference of Young Scientists and Graduate Students (April 4-25, 2016, Krasnodar), 1, 245-249. (In Russian)

24. Koz'min, G.V., Sanzharova, N.I., Kibina, I.I., Pavlov, A.N., Tihonov, V.N. (2015). Radiation technologies in agriculture and food industry. Achievements of Science and Technology of AIC, 29(5), 87-92. (In Russian)

25. Ivankin, A.N., Yushina, Yu.K., Gorbunova, N.A., Evdokimov, Yu.N. (2011). The study of the of nano-silver and sodium lactate complex using possibility to protect food products. Materials of the international scientificpractical conference. Volgograd State Technical University, GNU Volga Research Institute of production and processing of meat and dairy products, 2, 197-198. (In Russian)

26. Anshakova, V.V., Kershengolts, B.M., Zhukov, M.A. A method for increasing the shelf life of juices, whole milk, liquid dairy and other food products using the mechanochemical biopreparation NANOYAGEL. Patent RF, no.2437582. 2011. (In Russian)

27. Mihienkova, A.I., Mucha, Yu.P. (2011). Silver nanoparticles: the characteristic and stability of the antimicrobial action of colloidal solutions. Dovkíllya ta zdorov'ya, 1(56), 55-59. (In Russian)
28. Zakharova, O.V., Gusev, A.A., Altabaeva, Yu.V., Perova, S. Yu. (2018). Biological effects of freshly prepared and daily aqueous dispersions of copper nanoparticles and copper oxide on E. Coli bacteria. Nanotechnologies in Russia, 13(3-4), 69-75. (In Russian)

29. Zelenkov, V.N., Karpachev, V.V., Belonozhkina, T.G., Voropaeva, N.L., Lapin, A.A. (2017). The fatty acid composition of Abyssinian nougat seeds, their total antioxidant activity and the prospects for practical use of the Russian variety Lipchanin. Materials of the XII International Symposium June 19-23, 2017. S12-S14. (In Russian)

30. Zintsova, Ju. S., Rozhnov, E. D., Shkolnikova, M. N. (2015). Use apple juice as a substrate for the production of functional drinks on the basis of polyculture Oryzamyces indic. Technology and merchandising of the innovative foodstuff, 3(32), 37-42. (In Russian)

31. Zhumabekova, B.K., Zhumabekova, K.A. (2015). Technology for producing of the kombucha tea with the addition of oregano extract. Fundamental research, 2, 2370-2373. (In Russian)

32. Palagina, M.V., Bogoutdinova, A.A. (2012). Application of spikenard extracts in production of new kinds of non-alcoholic beer. Vestnik Pacific State University of Economics, 2,122-126. (In Russian)

33. Kotik, O.A. (2012). Prospects for plant extracts with high antioxidant activity use in fermentation kvass. News of institutes of higher tducation. Food Technology, 4(328), 26-29. (In Russian)

34. Lomanov, R.S. (2015). The use of an extract of Dahurian larch in the brewing and soft industries to obtain a functional beverage. Symbol of science, 11-1, 37-40. (In Russian)

35. Omasheva, A.C., Beisenbayev, A.U., Urazbayeva, K.A., Abishev, M.Z., Beisenbayeva Z.A. (2015). Investigation of the effect of herbal additive on the quality of medicinal kvass. Advances in current natural sciences, 1-4, 822-826. (In Russian)

36. Cherevach, E.I., Tenkovskaya, L.A., Pankova, M.E. (2013). The Plant Antioxidants for Simulating Non-Alcoholic Beverages of Bio Correctional Action. Beer and beverages, 4, 70-72. (In Russian)

37. Gerasimova, T.V., Evdokimov, I.A., Lodygin, A.D., Abakumova, E.A., Haritonov, D.V. (2012). Technology of the fermented milk: application of the extracts of vegetable raw materials. Dairy Industry, 2, 72-73. (In Russian)

38. Tolmachev, V.O., Tikhonov, S.L., Tikhonova, N.V (2016). The development of the technology of lucerne extract and its application for production of nonalcoholic beverages of the antioxidant activity. Bulletin of South Ural State University, Series "Food and Biotechnology", 4 (3), 47-54. (In Russian)

39. Bakin, I.A., Mustafina, A.S., Lunin, P.N. (2015). Improvement of technology of berry raw materials extracting with use of processing by ultrasound. Bulletin of KrasSAU, 12, 91-95. (In Russian)

40. Baraboy, V.A. (2008). Catechins of tea: structure, activity, application. Biotechnologia Acta, 3, 25-36. (In Russian)

41. Shlykova, A.P., Kolobaeva, A.A., Kotik, O.A. (2013). The plant extracts study as a raw material for the fermentation kvas production. Modern high technologies, 8-2, 319-320. (In Russian)

42. Babiy, N.V., Pekov, D.B., Bibik, I.V., Pomozova, V.A. (2009). New therapeu tic and prophylactic drinks based on plant antioxidants from the Far East. Beer and beverages, 3, 16-17. (In Russian)

43. Afanas'ev, I.V., Ostrachovich, E.A., Abramova, N.E., Korkina, L.G.(1995) Different antioxidant activities of bioflavonoid rutin in normal and iron-overloading rats. Biochemical Pharmacology, 50(5), 627-635. DOI: 10.1016/0006-2952(95)00173-w

44. Stevenson, D. E., Hurst, R. D. (2007). Polyphenolic phytochemicals - just antioxidants or much more? Cellular and Molecular Life Sciences, 64(22), 2900-2916. DOI: 10.1007/s00018-007-7237-1

45. Roginsky, V., Michel, S., Bors, W. (2000). Reactivity of Semiquinones with Ascorbate and the Ascorbate Radical as Studied by Pulse Radiolysis. Archives of Biochemistry and Biophysics, 384(1), 74-80. DOI: 10.1006 abbi.2000.2050

46. Boots, A. W., Kubben, N., Haenen, G., Bast, A. (2003). Oxidized quercetin reacts with thiols rather than with ascorbate: implication for quercetin supplementation. Biochemical and Biophysical Research Communications, 308(3), 560-565. DOI:10.1016/s0006-291x(03)01438-4

47. Awad, H. M., Boersma, M.G., Boeren, S., Bladeren, P.V.J., Vervoort, J., Rietjens, I.M.C.M. (2003). Ouenching of quercetin quinone/quinone methides by different thiolate scavengers: stability and reversibility of conjugate formation. Chemical Research in Toxicology, 16(7), 822-831. DOI 10.1021/tx020079g

48. Galati, G., Sabzevari, O., Wilson, J.X., O’Brien, P.J. (2002). Prooxidant activity and cellular effects of the phenoxyl radicals of dietary flavonoids and other polyphenolics. Toxicology, 177(1), 91-104. DOI: 10.1016/ S0300-483X(02)00198-1

49. Walle, T., Vincent, T.S., Walle, U. K. (2003). Evidence of covalent binding of the dietary flavonoid quercetin to DNA and protein in human intestinal and hepatic cells. Biochemical Pharmacology, 65(10), 1603-1610. DOI: 10.1016/s0300-483x (02) 00198-1

50. Kostyuk, V.A. (2016). Plant polyphenols as a component of functional foods. Proceeding $B G U, 11-1,32-41$. (In Russian)

51. Manach, C., Morand, C., Crespy, V., Demigné, C., Texier, O., Régérat, F., Rémésy, C. (1998). Quercetin is recovered in human plasma as conjugated derivatives which retain antioxidant properties. FEBS Letters, 426(3), 331-336. DOI: 10.1016/s0014-5793(98)00367-6 
52. Hollman, P.C., Trijpa, J. M.P., Mengelers, M., Vriesb, J.H.M., Katanb, M. B. (1997) Bioavailability of the dietary antioxidant flavonol quercetin in man. Cancer Letters, 114(1-2), 139-140. DOI: 10.1016/s03043835(97)04644-2

53. Vitaglione, P., Donnarumma, G., Napolitano, A., Galvano, F., Gallo, A., Scalfi, L., Fogliano, V. (2007). Protocatechuic acid is the major human metabolite of cyanidin-glucosides. Journal of Nutrition, 137(9), 20432048.

54. Izumi, T., Piskula, M.K., Osawa, S., Obata, A., Tobe, K., Saito, M., Kataoka, S., Kubota, Y., Kikuchi, M. (2000). Soy isoflavone aglycones are absorbed faster and in higher amounts than their glucosides in humans. Journal of Nutrition, 130(7), 1695-1699.

55. Spencer, J.P.E., Chowrimootoo, G., Choudhury, R., Debnam, E.S., Srai, S.K., Rice-Evans, C. (1999). The small intestine can both absorb and glucuronidate luminal flavonoids. FEBS Letters, 458(2), 224-230. DOI: 10.1016/s0014-5793(99)01160-6
56. Vitaglione, P., Donnarumma, G., Napolitano, A., Galvano, F., Gallo, A. Scalfi, L., Fogliano, V. Protocatechuic acid is the major human metabolite of cyanidin-glucosides. The Journal of Nutrition, 137(9), 2043-2048. DOI: 10.1093/jn/137.9.2043

57. Hollman, P.C.H. (2004). Absorption, bioavailability, and metabolism of flavonoids. Pharmaceutical Biology, 42(1), 74-83. DOI: $10.3109 / 13880200490893492$

58. Pietta, P.G. (2000). Flavonoids as antioxidants. Journal of Natural Products

59. 63(7), 1035-1042. DOI: 10.1021/np9904509

60. Serafini, M., Maiani, G., Ferro-Luzzi, A. (1997). Effect of ethanol on red wine tannin-protein (BSA) interactions. Journal of Agricultural and Food Chemistry, 459(8), 3148-3151. DOI: 10.1021/jf960864x

61. Booyse, F.M., Pan, W., Grenett, H.E., Parks, D.A., Darley-Usmar, V.M., Bradley, K.M., Tabengwa, E. M. (2007). Mechanism by which alcohol and wine polyphenols affect coronary heart disease risk. Annals of Epidemiology, 7(5), S24-S31. DOI: 10.1016/j.annepidem.2007.01.006

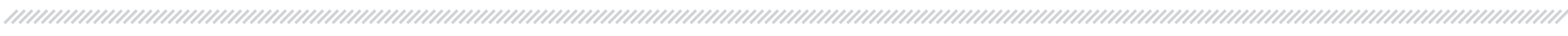

\section{AUTHOR INFORMATION}

Marina V. Gernet - professor, doctor of technical sciences, head of brewing technology department All-Russian Scientific Research Institute of Brewing, Beverage and Wine Industry - Branch of V.M. Gorbatov Federal Research Center for Food Systems of RAS, 119021, Moscow, Rossolimo str., 7. Tel.: +7-499-24510-79, e-mail: institut-beer@mail.ru

Irina N. Gribkova - candidate of technical sciences, senior researcher of brewing technology department, All-Russian Scientific Research Institute of Brewing, Beverage and Wine Industry - Branch of V.M. Gorbatov Federal Research Center for Food Systems of RAS, 119021, Moscow, Rossolimo str., 7. Tel.: +7-499-24604-47, e-mail: institut-beer@mail.ru

*corresponding author

Olga A. Borisenko - senior researcher of brewing technology department, All-Russian Scientific Research Institute of Brewing, Beverage and Wine Industry Branch of V.M. Gorbatov Federal Research Center for Food Systems of RAS, 119021, Moscow, Rossolimo str., 7. Tel.: +7-499-246-01-96, e-mail: institut-beer@ mail.ru

All authors bear responsibility for the work and presented data.

All authors made an equal contribution to the work.

The authors were equally involved in writing the manuscript and bear the equal responsibility for plagiarism.

The authors declare no conflict of interest.

Received 30.04.2019 Accepted in revised 14.11.2019 Accepted for publication 26.11.2019 